\title{
The Impossibility of a Paretian Liberal: Reply
}

\section{Citation}

Sen, Amartya Kumar. 1971. The impossibility of a Paretian liberal: Reply. Journal of Political Economy 79(6): 1406-1407.

\section{Published Version}

http://www.jstor.org/stable/1830113

\section{Permanent link}

http://nrs.harvard.edu/urn-3:HUL.InstRepos:3612780

\section{Terms of Use}

This article was downloaded from Harvard University's DASH repository, and is made available under the terms and conditions applicable to Other Posted Material, as set forth at http:// nrs.harvard.edu/urn-3:HUL.InstRepos:dash.current.terms-of-use\#LAA

\section{Share Your Story}

The Harvard community has made this article openly available.

Please share how this access benefits you. Submit a story.

Accessibility 


\section{The Impossibility of a Paretian Liberal: Reply}

Amartya Sen

University of Delhi

Professors Hillinger and Lapham's critique of my theorem on the impossibility of combining Conditions $P$ (Pareto principle), $L$ (liberalism), and $U$ (unrestricted domain) does not question the validity of the theorem but denies that my definition of Condition $L$ corresponds to the correct notion of liberalism. When writing my paper, I was afraid of definitional disputes, and after claiming that "Condition $L$ represents a value involving individual liberty that many people would subscribe to" (a sentence that Hillinger and Lapham quote), I added that "whether such people are best described as liberals is a question that is not crucial to the point of the paper" (a sentence that they do not quote). However, while the validity of the theorem is not in dispute, its practical importance will depend on the exact interpretation of liberalism; and, hence, Hillinger and Lapham are within their rights to question my definition of Condition $\mathrm{L}$.

The alternative interpretation of liberalism on which Hillinger and Lapham (henceforth, HL) base their paper, and which they claim to be "the only generally accepted principle of liberalism," is nowhere precisely defined by HL. It is only "broadly defined" (to quote their expression) in highly general terms, but they do spell out its implications fairly precisely. ${ }^{1}$ It appears from their definition that, whenever interpersonal interdependences are present, the principle of liberalism would not assert anything. "Whenever the choices of one individual impinge on the welfare of others there is no general presumption in favour of freedom of individual choice," and HL "are aware of no relatively value free principle of liberalism which could decide the issue in such a case" (p. 2). ${ }^{2}$ Liberalism, on this interpretation, would seem to demand freedom of individual action only when a person's action is not opposed by anyone else. It is clear why the principle of liberalism, thus defined, will not conflict with the Pareto principle: because it does not demand anything that the

$1 \mathrm{HL}$ are also quite precise in quoting my views, although frequently this precision is not matched by accuracy. For example, I neither hold nor have I stated or implied, as alleged by HL, that "liberal principles imply that it is worse to force person 1 to read a book he does not want to read than it is to prevent person 2 from reading a book he does wish to read" (p. 3).

2 Why should the principle of liberalism, which should give expression to liberal values, be expected to be "value free" is, however, not explained. 
Pareto principle does not also demand. ${ }^{3}$ Indeed, HL show not merely that their brand of liberalism is consistent with the Pareto principle, they show in effect that liberalism (according to their definition) is completely redundant in the presence of the Pareto principle.

Is this really "the only generally accepted principle of liberalism"? The Pareto principle is generally taken to be noncontroversial. By the HL interpretation, liberalism does not demand anything more and so must be also noncontroversial. Then what does the liberal assert? A typical problem of liberalism would arise, I imagine, when a person wants to do something (for example, read a book, wear a dress, or express some views) which some others (maybe a majority or even everybody else) think should not be done. But not so in the views of HL. Since the action in question will "impinge on the welfare" of other persons, the principle of liberalism, as seen by them, could not possibly apply here. "In conditions of interdependence, we cannot," say HL, "conceive of any "principle of liberalism' which would govern what actions are to be left to individuals, independently of the majority preference of the individuals concerned" (p. 3). Liberalism, on this interpretation, would say nothing on minority rights, nothing on the right to privacy, and nothing on noninterference in personal lives. It would defend a person's freedom of action only so long as nobody else objects to that action.

I would readily concede that my theorem asserted nothing about this empty box which HL call liberalism. This is, in fact, not a concession, it is an assertion.

3 The modification of my illustration with which HL conclude their paper is based on a confusion between (1) a condition on the functional relation between individual preferences and social choice, and (2) a specification of an arbitrary social ordering, irrespective of the individual preferences. Conditions $\mathrm{L}$ and $\mathrm{P}$, in my paper, are conditions in the former sense, whereas HL's "less bloody action should always be preferred" is an example of the latter. 